\title{
Pertumbuhan anak-anak usia 7-11 tahun di Surabaya: Ketidaksesuaian berat badan dengan referensi WHO
}

\section{7-11 aged Children's growth in Surabaya: Weight incompatibility with $\mathrm{WHO}$ references}

\author{
$\underline{\text { Sakina }}^{1, *}$, Fundhy S. I. Prihatanto ${ }^{1}$, Desy Purwidyastuti ${ }^{1}$, Myrtati D. Artaria ${ }^{2}$ \\ ${ }^{1}$ Departemen Anatomi dan Histologi, FK, Universitas Airlangga, Surabaya, Indonesia. \\ ${ }^{2}$ Departemen Antropologi, FISIP, Universitas Airlangga, Surabaya, Indonesia \\ Korespondensi: Sakina, Departemen Anatomi dan Histologi, FK, Universitas Airlangga, \\ Jalan Prof. Dr. Moestopo, Surabaya, Indonesia. E-mail:sakinahusen@ yahoo.com
}

\begin{abstract}
Body size is strongly considered in making medical decisions, selecting medical instruments, drug dosing, and asessment of children's growth. References of body size based on Caucasian population are widely used nowadays. Unfortunately, these references might have significant differences with others population. A specific study in Indonesian population is needed especially to make its own reference of growth. This research is aimed to get body weight (BW) data from children aged 7-11 years in Surabaya. This research was conducted to 656 children aged 7-11 years. Anthropometer was used to get BW data. Measurement was performed in the morning. All data were plotted to WHO growth chart. Based on the data percentils, we created BW growth chart for specific age and sex.We found an increasing trend with increasing age especially in girls. The increasing trend is better observed in girls. BW data which was plotted to WHO growth chart revealed that in many younger children had normal body weight and even overweight, unfortunately when entering pubertal age some of these children were underweight. Older children has lineary correlated with BW. Data plotting to WHO growth chart reveals that the younger children grew normally according to the reference, but then at later phase they did not follow the reference. This trend is similar to a previous studies, so that this strenghten our supposition that the difference between the WHO Growth Chart and the body growth of children in Indonesian area is not caused by lack of nutrition.
\end{abstract}

Keywords: growth, growth chart, children, growth reference, anthropometry

\begin{abstract}
Abstrak
Ukuran tubuh sangat dipertimabngkan untuk pembuatan keputusan-keputusan medis, pemilihan instrumen medis, dosis obat, dan asesmen pertumbuhan badan anak. Referensi tentang besar tubuh selama ini adalah berdasar populasi Europoid. Sayangnya, referensi ini mungkin mempunyai perbedaan dengan populasi lain di dunia. Penelitian ini mempelajari tumbuh kembang anak-anak di Indonesia, untuk mempertimbangkan kemungkinan dibutuhkannya referensi tumbuh kembang tersendiri. Tujuan penelitian ini adalah untuk mendapatkan rata-rata berat badan dari anak-anak usia 7-11 tahun di Surabaya. Penelitian dilakukan di Surabaya dengan mengukur 656 anak usia 7-11 tahun. Pengukuran dilakukan pada pagi hari. Semua data di plot pada referensi WHO Growth Chart. Berdasar persentil data, ditemukan grafik berat badan untuk masing-masing umur dan jenis kelamin. Kami temukan tren meningkat pada perempuan. Jika dibandingkan WHO, banyak anak-anak ini yang mempunyai berat badan normal atau overwight. Akan tetapi ketika masuk masa puber, banyak yang masuk kategori underweight jika dibandingkan dengan WHO Growth Chart. Tren ini serupa dengan penelitian yang dilakukan di era sebelumnya, sehingga memperkuat dugaan bahwa ketidaksesuaian berat badan anak-anak di Surabaya di masa puber, jika dibanding dengan WHO growth chart bukanlah karena kekurangan gizi.
\end{abstract}

Kata Kunci: tumbuh kembang, grafik pertumbuhan, anak, referensi pertumbuhan, antropometri

\section{Pendahuluan}

Pertimbangan ukuran tubuh sangat diperlukan dalam penanganan kegawatdaruratan sehingga diperlukan dasar antropometri yang baik. Ukuran tubuh digunakan untuk menentukan tindakan, 
pemilihan instrumen medis dan penentuan dosis obat yang digunakan. Ukuran tubuh yang dipakai saat ini dikembangkan berdasarkan penelitian dari populasi Kaukasoid. Ukuran tersebut dapat mempunyai beda bermakna bila diaplikasikan pada populasi Indonesia. Pada suatu keadaan gawat darurat, ketepatan ukuran tubuh menjadi sangat penting terkait kemampuan cadangan tubuh yang menjadi sangat terbatas.

Salah satu metode untuk mengukur pertumbuhan adalah antropometri. Salah satu ukuran antropometri yang sering digunakan adalah berat badan (BB). Pelaporan BB yang salah akan menyebabkan tidak tepat dosis, sehingga tidak tepat terapi dan akhirnya merubah perkiraan prognosis (Finardi et al. 2012). Selain ukuran tubuh, dalam pertumbuhan yang perlu diketahui adalah kemampuan fungsional seorang individu (Henneberg\& Louw 1998) yang dilihat dari fungsi neuromuskular dan kardiorespirasi (Norgan 1994). Dengan kebugaran neuromuskular yang baik diharapkan anak mempunyai insiden cedera yang rendah (Collard et al. 2010).

Pembuatan referensi pertumbuhan anak secara internasional awalnya disebabkan adanya secular trend terutama pada masa tumbuh kembang sehingga referensi baru tentang pertumbuhan anak dibuat olehWorld Health Organization (WHO) yang bekerja sama dengan berbagai organisasi (Butte et al. 2007). Pertumbuhan anak bukan hanya tentang pertambahan ukuran namun juga kemampuan untuk berfungsi dan melaksanakan aktivitas (Henneberg \& Louw 1998).

Variabilitas antar populasi menyebabkan satu referensi tidak bisa diterapkan untuk keseluruhan populasi dunia.Sebagai contoh penggunaan indeks massa tubuh (IMT) untuk mendeteksi berat badan (BB) kurang atau lebih didasarkan pada populasi Kaukasoid sehingga tidak bisa digunakan secara luas (WHO 2000, WHO 1995 cit. Wenget al. 2006, Rushet al. 2009). Populasi Asia memiliki lemak tubuh yang lebih banyak dibandingkan dengan populasi Kaukasoid (Deurenberget al,1998 cit. Liuet al. 2011). Penggunaan referensi IMT yang tidak sesuai akan mengakibatkan estimasi yang kurang atau berlebihan dalam menilai status kesehatan (Nishidaet al. 2010). Lebih lanjut lagi WHO merekomendasikan penggunaan lingkar perut (LP) dan rasio perut pinggang (RPPi) sebagai indikator obesitas di populasi Asia (Nishidaet al. 2010). Norgan (1994) menyebutkan bahwa komposisi tubuh merupakan salah satu faktor yang mempengaruhi performa fisik yang pada akhirnya akan mempengaruhi aktivitas fisik individu.

Studi yang dilakukan Butte et al. (2007) mencakup 5 daerah utama di Afrika, Asia Timur, Asia Selatan, Asia Barat dan Eropa dan membandingkan antara data pertumbuhan anak-anak yang sehat dan unggul dari daerah-daerah tersebut dengan referensi dari National Center for Health Statistics(NCHS)/WHO. Beberapa populasi di Eropa Tengah, Asia Selatan dan Asia Barat mempunyai tinggi badan rata-rata di bawah referensi NCHS/WHO (Butte et al. 2007).

Penelitian di Indonesia oleh Tuan dan Nicklas (2009) menggunakan data longitudinal sejak tahun 1990an berhasil mencakup 11.756 anak-anak usia 2-18 tahun dari 13 provinsi di Indonesia. Pengukuran yang dilakukan hanya menggunakan IMT sebagai indikator pertumbuhan dengan referensi berdasar dari Centers for Disease Control and Prevention (CDC) yang juga digunakan oleh WHO dan referensi dari International Obesity Task Force (IOTF) yang menunjukkan prevalensi BB lebih sebesar 2-5\% dan BB kurang sebesar 18-34\%. Penetapan prevalensi ini masih mempunyai kelemahan karena referensi pertumbuhan anak untuk tiap populasi tidak sama. Oleh karena itu perlu dimulai melakukan penelitiansecara luas pada berbagai populasi di Indonesia untuk mencari referensi pertumbuhan yang sesuai sehingga dapat digunakan untuk menilai status gizi anak dengan tepat.

Sebagai gambaran, CDC telah melakukan survei di Amerika Serikat selama 31 tahun terhadap 30.000 anak, sedangkan IOTF telah melakukan survei di Brazil, Inggris, Hong Kong, Belanda, Singapura dan Amerika Serikat selama 30 tahun terhadap 200.000 anak sebelum mengeluarkan referensinya (Tuan \& Nicklas 2009). Di Indonesia sendiri, untuk langkah awal dapat dilakukan penelitian di Surabaya sebagai kota dengan penduduk yang cukup padat dan variasi etnisnya sangat beragam.

Berdasarkan uraian di atas maka penelitian ini bertujuan untuk mendapatkan data BB untuk kemudian dibuat kurva pertumbuhan untuk anak usia 7-11 tahun di Surabaya berdasar jenis kelamin 
dan kelompok umur. Data BB yang didapat kemudian diplot ke kurva WHO BB/U. Dengan demikian dapat menjawab pertanyaan apakah berat badan anak-anak pada kelompok sampel ini sesuai dengan referensi tumbuh kembang yang selama ini direkomendasi oleh WHO. Juga dapat ditelaah apakah diperlukan referensi tumbuh kembang yang berbeda dari WHO, yang lebih sesuai dengan tumbuh kembang anak-anak di Indonesia. Hal ini penting karena dengan adanya referensi pertumbuhan dan perkembangan anak yang sesuai, akan didapatkan gambaran fungsional terkait dengan pencegahan terhadap terjadinya cedera. Dengan karakteristik fungsional yang baik, anak-anak akan mempunyai risiko lebih rendah terhadap cedera, lebih siap menghadapi kegawatdaruratan, menurunkan insidensi penyakit, sehingga dapat beraktivitas (terutama belajar) dengan baik (Ortegaet al. 2008).

\section{Metode Penelitian}

Jenis penelitian adalah penelitian cross sectional analitik (Ghazali et al. 1995). Rancangan penelitian ini dilakukan untuk mengetahui nilai rata-rata normal berikut simpangannya dari berat badan pada setiap kelompok usia di setiap jenis kelamin di Surabaya beserta hubungan antar variabelnya.

Pada penelitian ini yang diteliti adalah Surabaya karena karakteristik kota sebagai pusat pemerintahan dan perdagangan di Jawa Timur dan diperkirakan memenuhi jumlah sampel yang dibutuhkan dalam tiap kelompok umur.Surabaya dipilih menjadi lokasi penelitian karena kota ini adalah terbesar kedua di Indonesia, dan sebagian besar penduduknya adalah Indonesia asli, sesuai dengan tujuan penelitian ini. Selain itu, penduduk mudah mengakses berbagai jenis makanan dengan harga yang wajar, sehingga kemungkinan anak-anak usia 7-11 tahun untuk mengalami kekurangan kalori adalah sangat kecil. Penelitian dilakukan terhadap 656 siswa Sekolah Dasar di Surabaya yang berusia antara 7-11 tahun, jenis kelamin laki-laki dan perempuan.

Sampel diambil dari anak berusia 7-11 tahun yang sedang bersekolah. Pemilihan sampel ditentukan berdasar kelompok umur pada wilayah tertentu. Teknik pengambilan sampel menggunakan stratified random sampling berdasarkan kelompok umur pada wilayah tertentu. Sekolah terpilih setelah memenuhi kriteria seleksi sebagai berikut: sekolah umum: siswa sekolah tersebut mewakili populasi umum di kecamatan tersebut, mempunyai siswa yang berasal dari tingkat sosial ekonomi yang sebanding dengan keadaan di kecamatan tersebut. Siswa terpilih setelah memenuhi kriteria seleksi berikut: bersedia menjadi subyek penelitian(SP) yang dibuktikan dengan adanya informed consent, tidak sedang sakit saat pelaksanaan pengukuran.

Pengukuran idealnya dilakukan pada pagi hari. Sebelum melakukan pengukuran BB ada baiknya mengetahui berat pakaian yang sedang digunakan oleh SP. Bila tidak memungkinkan, hasil yang didapat dari pengukuran bisa dikoreksi $1 \mathrm{~kg}$ sebagai perkiraan berat pakaian (Guricci et al. 1999). Pengukuran idealnya dilakukan pada pagi hari pada jam yang sama setiap harinya (Marfell-Jones 2006). Pengukuran BB dilakukan dengan penimbang berat badan digital yang portabel (Camry, Republik China) dengan ketelitian alat $0,1 \mathrm{~kg}$.

\section{Hasil dan Pembahasan}

Tabel 1 adalah data rata-rata dan simpangan baku berat badan pada masing-masing kelompok sampel. Pada tiap jenis kelamin kemudian dibuat grafik nilai BB-nya. Berdasarkan tabel 1. nampak bahwa secara umum rata-rata berat badan perempuan lebih tinggi bila dibandingkan dengan laki-laki yang seusia. Pada kelompok usia 7 tahun, rata-rata berat badan perempuan lebih rendah bila dibandingkan dengan laki-laki, sedangkan pada kelompok usia 11 tahun rata-rata berat badan perempuan jauh lebih tinggi bila dibandingkan dengan laki-laki. Berdasarkan tabel juga tampak bahwa rata-rata berat badan baik laki-laki maupun perempuan akan semakin tinggi seiring dengan meningkatnya usia. 
Tabel 1.

Rata-rata berat badan (dalam kg) dan simpangan bakunya

\begin{tabular}{|c|c|c|c|c|c|c|}
\hline \multirow{2}{*}{$\begin{array}{l}\text { Usia } \\
\text { (tahun) }\end{array}$} & \multicolumn{3}{|l|}{ Laki-laki } & \multicolumn{3}{|c|}{ Perempuan } \\
\hline & $\begin{array}{l}\text { Rata-rata } \\
\text { badan }\end{array}$ & berat & $\begin{array}{l}\text { Simpangan } \\
\text { baku }\end{array}$ & $\begin{array}{l}\text { Rata-rata } \\
\text { badan }\end{array}$ & berat & Simpangan baku \\
\hline 7 & 22.57 & & 5.45 & 21.82 & & 7.27 \\
\hline 8 & 23.51 & & 4.67 & 24.64 & & 6.68 \\
\hline 9 & 26.6 & & 9.35 & 29.4 & & 8.78 \\
\hline 10 & 29.7 & & 8.46 & 30.3 & & 10.4 \\
\hline 11 & 33.5 & & 10.03 & 36.9 & & 9.9 \\
\hline
\end{tabular}

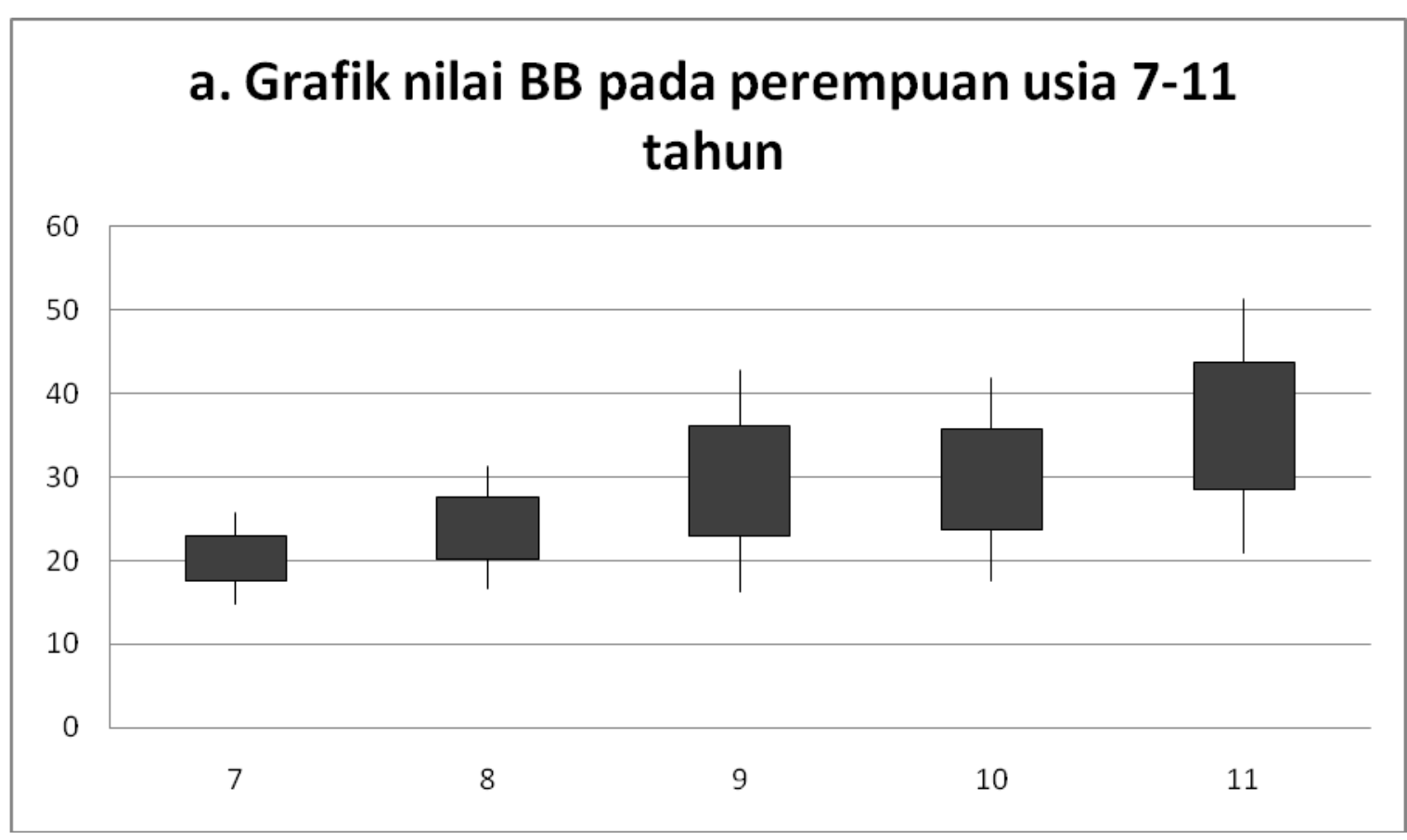

Gambar 1.

Grafik nilai berat badan perempuan (a) dan laki-laki (b) pada masing-masing kelompok usia

Berdasarkan grafik nampak bahwa rentang BB paling besar baik pada laki-laki dan perempuan adalah pada kelompok usia 9 dan 10 tahun. Tren peningkatan BB lebih jelas terlihat pada perempuan.

Kurva pertumbuhan berdasarkan BB dapat dibuat bila diketahui nilai persentil baik pada laki-laki dan perempuan pada masing-masing kelompok usia. Persentil yang digunakan sesuai dengan kurva persentil dari WHO tahun 2007 yaitu persentil 3, 15, 85 dan 97. 


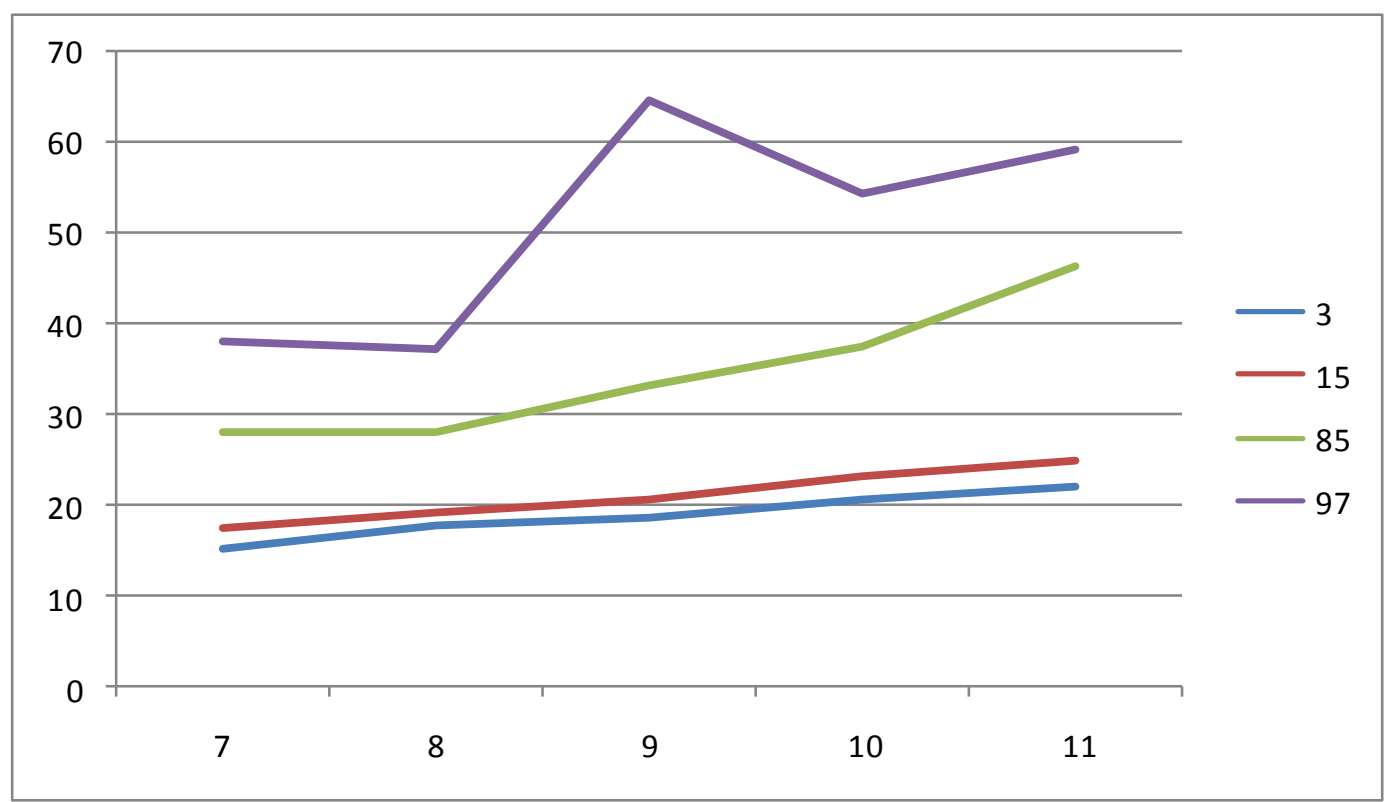

Gambar 2.

Kurva persentil BB usia 7-11 tahun pada laki-laki

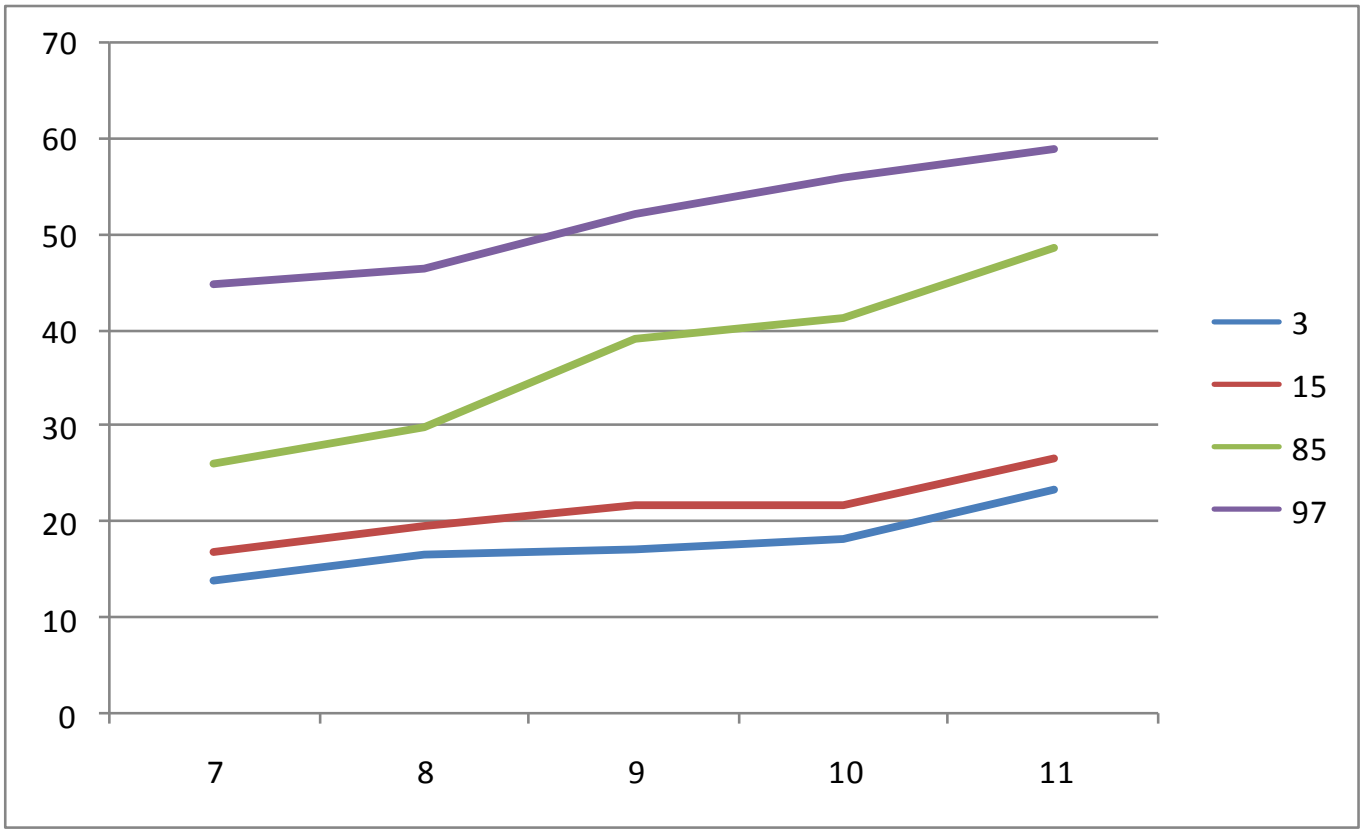

Gambar 3.

Kurva persentil BB usia 7-11 tahun pada perempuan

Hampir sama seperti laki-laki, persentil 3 dan 15 saling berdekatan. Rentang data paling besar terdapat pada persentil 85. Secara umum terdapat tren peningkatan BB pada semua persentil, namun peningkatan ini mulai nampak pada usia 10 tahun. 

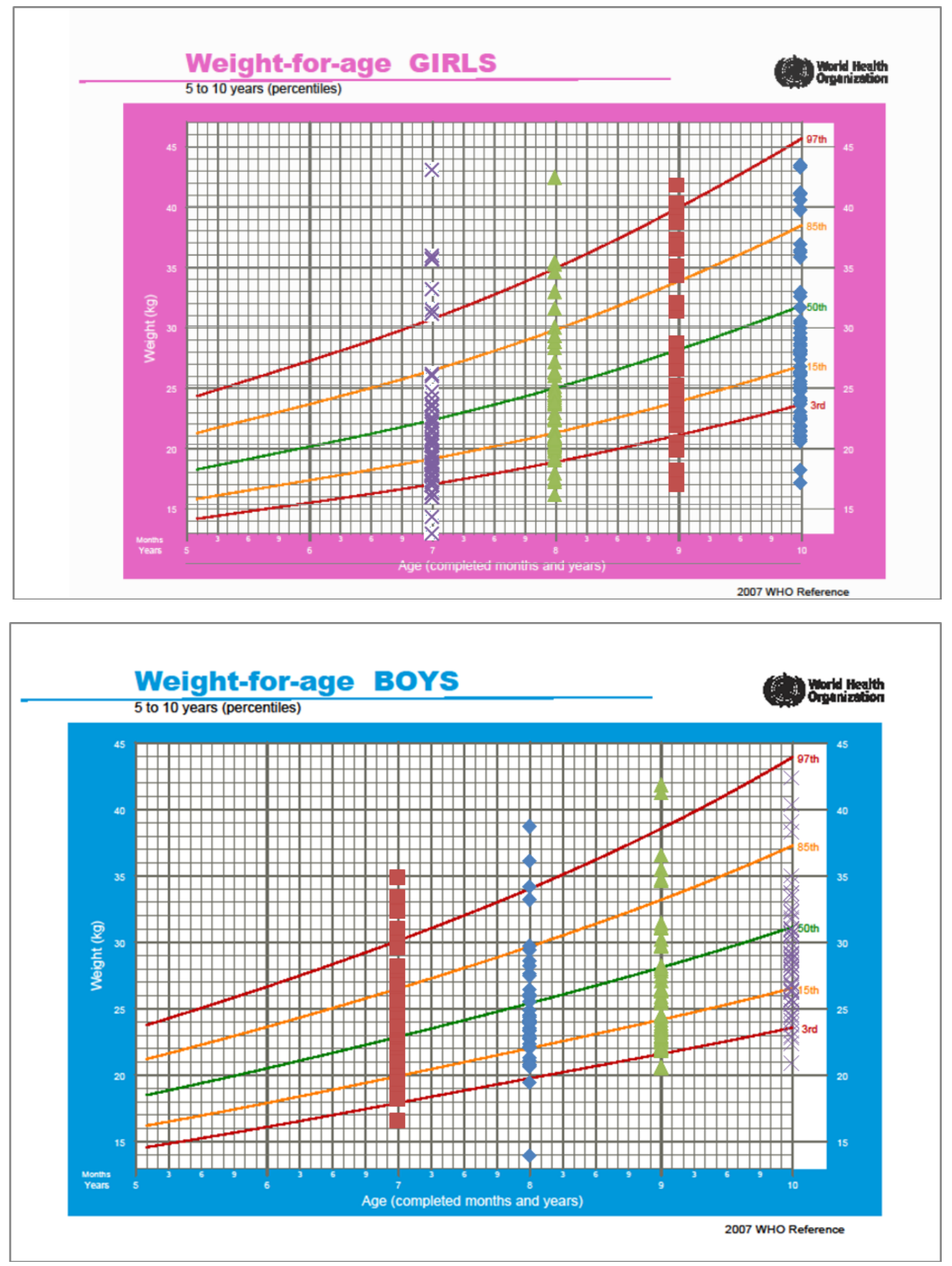

Gambar 4.

Kurva persentil BB WHO untuk perempuan (atas) dan laki-laki (bawah)

Pada kurva nampak bahwa BB perempuan pada sebagian kecil sampel berada pada kelompok BB kurang dan BB lebih, namun pada kelompok usia 10 tahun sebagian kecil sampel berada pada daerah BB kurang dan tidak ada yang berada pada daerah BB lebih. Lain halnya dengan anak laki-laki, hanya 1-2 sampel yang berada pada daerah BB kurang, sebagian besar berada pada BB normal dan sebagian kecil berada pada daerah BB lebih. Hal ini menunjukkan bahwa kasus BB lebih lebih sering ditemukan pada anak laki-laki daripada anak perempuan. 
Adanya pola pertumbuhan yang awalnya sesuai referensi namun di usia lebih tua tidak sesuai referensi dimungkinkan karena penelitian ini adalah cross sectional sedangkan referensi yang digunakan berasal dari studi longitudinal. Kemungkinan lain adalah bahwafenomena ini disebabkan oleh ketidaksesuaian antara populasi yang menjadi sumber referensi dengan populasi penelitian, seperti pernah ditunjukkan oleh beberapa penelitian di tempat lain (Wenget al. 2006, Rushet al. 2009, Deurenberget al.1998 cit. Liuet al. 2011). Tren ini serupa dengan penelitian yang dilakukan di era sebelumnya di Kota Malang (Artaria 2001), sehingga memperkuat dugaan bahwa ketidaksesuaian berat badan anak-anak di Surabaya di masa puber, jika dibanding dengan WHO growth chart bukanlah karena kekurangan gizi.Maka diduga pertumbuhan anak-anak Indonesia memiliki pola yang berbeda dengan pertumbuhan pada populasi Kaukasoid. Jika demikian maka diperlukan referensi tumbuh kembang yang datanya berasal dari anak-anak Indonesia yang sehat.

\section{Simpulan}

Pertambahan BB sejalan dengan pertambahan usia. Pada anak-anak yang lebih muda didapatkan banyak anak yang dapat mengikuti referensi WHO bahkan berada di daerah BB lebih, namun pada anak-anak yang lebih tua beberapa anak cenderung berada di daerah BB kurang. Kurangnya BB ini tentu saja sejalan dengan juga kurangnya tinggi badan, karena jika anak berbadan tinggi lazimnya berat badan juga lebih berat, dan sebaliknya. Kurangnya rata-rata anak-anak Indonesia, dalam hal ini sampel di Surabaya, dibanding referensi ini, tentu tidak perlu disimpulkan bahwa berarti kekurangan gizi, tetapi perlu dilihat gambar secara lebih menyeluruh tentang perbedaan antar populasi dalam hal tumbuh kembang anak. Tren ini serupa dengan penelitian-penelitian yang dilakukan di era sebelumnya, sehingga memperkuat dugaan bahwa ketidaksesuaian berat badan anak-anak di Surabaya di masa puber, jika dibanding dengan WHO growth chart bukanlah karena kekurangan gizi.Diperlukan referensi baru untuk pertumbuhan anak di Indonesia. Penelitian lanjutan dengan jumlah sampel yang lebih besar, dari berbagai populasi di Indonesia. Pengambilan data dapat dilakukan baik secara longitudinal maupun cross sectional. Untuk pembuatan referensi tumbuh kembang, akan diperlukan data dari anak-anak yang sehat dan mengalami tumbuh kembang dengan baik.

\section{Daftar Pustaka}

Artaria MD (2001) Growth of Javanese children in Malang. In: Henneberg M \& Kilgariff J. (Eds.). Causes and Effects of Human Variation. Australasian Society of Human Biologist.

Butte NF, Garza C, and de Onis M (2007) Evaluation of the feasibility of international growth standards for school-aged children and adolescents. The Journal of Nutrition 137: 153-157.

Collard DCM, Chinapaw MJM, Verhagen EALM, Bakker I, van Mechelen W (2010) Effectiveness of a school-based physical activity-related injury prevention program on risk behavior and neuromotor fitness a cluster randomized controlled trial. International Journal of Behavioral Nutrition and Physical Activity 7:9.

Finardi P, Nickel CH, Koller MT, Bingisser R (2012) Accuracy of self-reported in a high risk geriatric population in the emergency department. Swiss Medical Weekly 142.

Guricci S, Hartriyanti Y, Hautvast JGAJ, and Deurenberg P (1999) Differences in the relationship between body fat and body mass index between two different Indonesia ethnic groups: The effect of body build. European Journal of Clinical Nutrition 53: 468-472.

Henneberg M and Louw GJ (1998) Cross-sectional survey of growth of urban and rural "Cape coloured" school children: Anthropometri and functional test. American Journal of Human Biology 10: 73-85.

Krejcie RV \& Morgan, DW (1970) Determining sample size for research activities, Educational and Psychological Measurement 30: 607-610.

Liu A, Byrne NM, Kagawa M, Ma G, Poh BK, Ismail MN, Kijboonchoo K, Nasreddine L, Trinidad TP, and Hills AP (2011) Ethnic differences in the relationship between body mass index and percentage body fat among Asian children from different backgrounds. British Journal of 
Nutrition 106: 1390-1397.Marfell-Jones M, 2006. Kinanthropometric assessment. Diakses dari http:// homepages.ihug.co.nz/ rip/Anthropometry/ tanggal 14 Maret 2013.

Norgan NG (1994) Anthropometry and physical performance. In Ulijaszek SJ and Mascie-Taylor CGN, eds. Anthropometry: The Individual and The Population. New York: Cambridge University Press. hal. 141-156.

Nishida C, Ko GT, and Kumanyika S (2010) Body fat distribution and noncommunicable disease in populations: overview of the 2008 WHO expert consultation on waist circumference and waist-hip ratio. European Journal of Clinical Nutrition 64: 2-5.

Rush EC, Freitas I, and Palnk LD (2009) Body size, body composition and fat distribution: comparative analysis of European, Maori, Pacific Island and Asian Indian adults. British Journal of Nutrition 102: 632-641.

Tuan NT and Nicklas TA (2009) Age, sex and ethnic differences in the prevalence of underweight and overweight, defined by using the CDC and IOTF cut points in Asian children. European Journal of Clinical Nutrition 63: 1305-1312.

Weng X, Liu Y, Ma J, Wang W, Yang G, Caballero B (2006) Use of body mass index to identify obesity-related metabolic disorders in the Chinese population. European Journal of Clinical Nutrition 60: 931-937.

World Health Organization, International Association for the Study of Obesity \& International Obesity Task Force (2000) The Asia-Pacific Perspective: Redefining Obesity and Its Treatment. Sydney: Health Communications. 